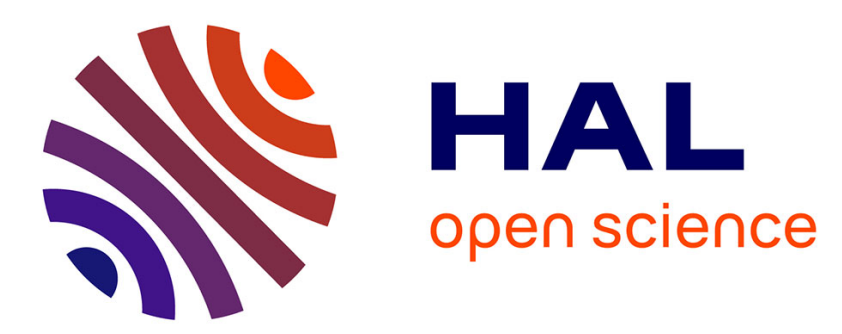

\title{
Labour Mobility in Construction: European Implications of the Laval un Partneri Dispute with Swedish Labour
}

Charles Woolfson, Jeff Sommers

\section{To cite this version:}

Charles Woolfson, Jeff Sommers. Labour Mobility in Construction: European Implications of the Laval un Partneri Dispute with Swedish Labour. European Journal of Industrial Relations, 2006, 12 (1), pp.49-68. 10.1177/0959680106061371 . hal-00570949

\section{HAL Id: hal-00570949 \\ https://hal.science/hal-00570949}

Submitted on 1 Mar 2011

HAL is a multi-disciplinary open access archive for the deposit and dissemination of scientific research documents, whether they are published or not. The documents may come from teaching and research institutions in France or abroad, or from public or private research centers.
L'archive ouverte pluridisciplinaire HAL, est destinée au dépôt et à la diffusion de documents scientifiques de niveau recherche, publiés ou non, émanant des établissements d'enseignement et de recherche français ou étrangers, des laboratoires publics ou privés. 
( 2006 SAGE (London, Thousand Oaks, CA and New Delhi)

Volume 12 Number 1 pp 49-68 www.sagepublications.com

Charles Woolfson and Jeff Sommers

University of Latvia and Stockholm School of Economics, LATVIA

\title{
Labour Mobility in Construction: European Implications of the Laval un Partneri Dispute with Swedish Labour
}

\begin{abstract}
The accession to the European Union of new member states from central and eastern Europe, with weak trade union movements, poorly developed social dialogue and inferior working conditions, has been viewed as a threat to regulated labour standards in the EU-15. This article examines a high-profile labour dispute arising from the conditions of Latvian construction contract labour in Sweden. The dispute exposes weaknesses in the protective floor of minimum standards offered by the posted workers Directive. It also goes to the core of the debate about the preservation of a 'European social model' and the proposed Services Directive. KEYWORDS: EU enlargement - European social model - posted workers Directive - labour standards - industrial disputes - construction industry
\end{abstract}

\section{Introduction: 'Swedish laws in Sweden'}

Between November 2004 and February 2005, angry Swedish construction workers, holding placards proclaiming 'Swedish laws in Sweden,' blockaded an old school undergoing renovation in a Stockholm suburb. They were protesting at the employment on the site of low-wage Latvian construction workers. The dispute demonstrates in microcosm the major challenges facing labour regulation in the expanded EU. It exposes the fragile nature of hard-won labour standards in the face of economic liberalization, deregulation and European enlargement.

The dispute analysed here goes to the very heart of the inherent contradiction in the European political project, between the free movement of labour and capital and the increasingly contested and precarious preservation of a European 'social model', with the promise of a guaranteed floor of rights for workers throughout the EU (Vaughan-Whitehead, 2003). The acquis communautaire receives its standard-setting potential 
from Community legislation such as the posted workers Directive, one of the key issues of contention during this dispute. Yet Europe's 'social dimension' would appear to be in danger of crumbling within months of enlargement, heralding the predicted 'race to the bottom' in labour standards (Kvist, 2004). The implications of this dispute suggest it is the first gust in a cold, possibly poisonous, 'eastern' wind blowing across the industrial relations landscape of the new Europe.

\section{Methodology}

The research for the current article was conducted by the authors, who are currently based in the Baltic region. Extensive use has been made of local and regional press sources, including those of Latvia and Sweden. Other documentary sources include industry statements from employers and trade union organizations in each country, as well as letters and documents of relevant governmental authorities. Where possible, to facilitate reader access, references are made to English-language sources. The focus on a single dispute is justified as a strategic case study, the first of its kind in the recent post-enlargement context. It is more than a mere 'blip' on the smooth trajectory of emerging European industrial relations. The arrival of the new member states from central and eastern Europe (CEE) poses considerable obstacles for any high-road 'convergence' in European industrial relations (Kohl and Platzer, 2004). Detailed empirical examination of the 'export' of some of the more problematic aspects of post-communist labour organization has been relatively neglected thus far. Consideration of the challenges these may pose to the future of regulated labour markets in Europe is overdue.

The specific impacts of labour mobility on labour regulation and national bargaining systems in the European construction industry have been analysed by Druker and Dupré (1998), and more recently, in relation to the new member states, by Clarke et al. (2003) and Sandberg et al. (2004). However, while many of the issues discussed here were prefigured in the context of the earlier 'enlargement' which incorporated East Germany, the Swedish-Latvian labour conflict reveals a new potential vulnerability in existing labour standards. The impact of the posted workers Directive in the sensitive area of the mobility of construction workers goes to the core of the problems discussed here (Cremers and Donders, 2005).

The article begins with a short analysis of the two contrasting trajectories of Sweden, an advanced social democracy, and Latvia, one of the most enthusiastic exponents of neo-liberal policies in post-communist eastern Europe. We describe the course of the dispute, with emphasis on its rapid politicization into a contest between the two governments. Key 
issues raised by the dispute are the application of the posted workers Directive in relation to service providers from new member states, the transposition of this Directive in the context of Swedish national provisions, and finally, the threat of an emerging 'race to the bottom' in labour standards in the EU-25.

\section{Exploiting Comparative Advantage Between States}

Geographical proximity aside, Sweden and Latvia could not be more different. Sweden is a model of Nordic social-democratic inclusiveness and developed civil society, in which organized labour has a central, legitimized role. Neo-liberal Latvia is the most impoverished of the new member states from the CEE (Dennis and Guio, 2003; Russell and Whelan, 2004) and displays a whole legacy of problems, including polarizing ethnic relations, growing social inequality, significant levels of corruption and, not least, poor working conditions (Antila and Ylöstalo, 2003; Zepa, 2004). Both countries share an older Baltic history and Latvia's capital, Riga, was once part of the Swedish empire; but their experience diverged significantly once Latvia became part of the Russian empire, and especially with the upheavals of the 20th century.

Sweden's modern prosperity has resulted from a combination of social cohesion, high productivity and high wages. While upward wage pressure stimulated increased productivity, labour and business cooperated to ensure that a balance was achieved between wages, investment and profits that would fuel growth and prosperity. Rising wages forced managers and entrepreneurs to organize production and services more effectively and efficiently. That process translated into both economic growth and the expansion of democracy, including the strong rights of labour to free collective bargaining (Elvander, 2002; Stokke and Thörnqvist, 2001). Organized labour contributed to affluence by demanding more of the goods they produced and the right to make them under humane conditions. It took the more efficient deployment of labour to achieve the economic 'miracle' of the post-1945 era and to consolidate these gains, rather than an inefficient global chase to find the world's cheapest wages (Palley, 1998).

By contrast, Latvia's post-Soviet inheritance has left it with uncertain prospects for economic development. Among the new market economies, Latvia has adopted some of the most neo-liberal policies in order to attract foreign direct investment (FDI). Its standard rate of corporate income tax was reduced in January 2004 to 15 percent, among the lowest in Europe and the source of some disquiet in the EU-15 (Latvian Investment and Development Agency, 2004); in the EU-25, only Cyprus and Ireland have lower rates. This strategy succeeded in attracting incoming 
foreign investment, at least in the short term, with Latvia ranking sixth among the new member states in the volume of FDI per capita (though some of this figure represents funds returning from foreign tax havens utilized by Latvian firms) and achieving a GDP growth rate of nearly 9 percent in 2004 (Republic of Latvia, 2004). FDI is viewed as essential for the economy because Latvia produces so much less than it consumes, with a current account deficit also of 9 percent (IMF, 2004).

In the political and ideological vacuum of post-communism, the neoliberal paradigm has seemed an attractive option in the CEE region, especially in the Baltic States (OECD, 2003): the advance of the 'Washington consensus' in the former Soviet bloc has appeared unstoppable (Gowan, 1999). Latvia's political and business elites seem intent on maintaining a subservience to the 'American way' (also demonstrated by participation in the war in Iraq) that risks parodying Latvia's subordination to Moscow during the Soviet era. With the future path of economic development so compromised, and being unable to match the flood of FDI inflows and advanced technology from abroad, the temptation for domestic entrepreneurs to seek an easier road through cut-price labour and intensive subcontracting is seductive. The compulsion to exercise this comparative advantage in the wider European context, as in the case to be analysed here, will doubtless continue its powerful pull in the context of the enlarged EU.

In Latvia today, trade union membership is estimated (probably optimistically) as 20 percent of the workforce and is overwhelmingly concentrated in the public sector ( 38 percent, as against 8 percent in the private sector). This is somewhat higher than in many other post-Soviet states, or for that matter the USA, but significantly below the European average, and far below the Swedish rate of more than 80 percent (EIROnline, 2004b). Despite some evidence of underlying support for trade unionism and occasional outbursts of militancy, organized labour in Latvia is on the defensive (Antila and Ylöstalo, 2004: 16; EIROnline, 2004f, 2004g). At the level of 'peak organizations', as elsewhere in the new market economies of CEE, organized labour has until now been entrapped in a tripartite, corporatist 'social dialogue'. This has mainly served to secure social peace during the process of neo-liberal reconstruction and has probably inhibited the development of 'bipartite' social dialogue at workplace and sectoral levels (Mailand and Due, 2004; Ost, 2000).

The representational weakness of labour is compounded by a substantial 'informal' or 'hidden' economy. 'Envelope wages' often comprise the chief form of payment, as in most CEE states, resulting in significant levels of 'undeclared' pay. One indication of the scale of this phenomenon is the relatively low level of declared pay in the private sector in Latvia: on average, it is 21.4 percent lower than in the public sector; while in sectors such as construction, where undeclared work is traditional, the 
disparity is even greater (32.5 percent) (EIROnline, 2004a). Labour protection standards are non-existent in the 'grey/black' economies, which are variously estimated to range between 15 percent and 45 percent of total employment in Latvia, and at a conservative minimum to account for around 18 percent of GDP, among the highest in the new member states (EIROnline, 2004e; Renooy et al., 2004). Such 'undeclared work' is typically insecure, and is a continuous threat to the establishment of more permanent, regulated employment contracts. All of these problems, as in other new member states, are of particular importance in the construction sector, where collective labour relations have largely disintegrated (Clarke et al., 2003).

Industrial fatality rates in Latvia are currently the highest in the EU25 (Eurostat, 2004), and in the construction industry are roughly three times the EU average. Accident rates are rising, a consequence according to the authorities of 'inadequate organization of work within companies, poor division of working hours, badly organized rest periods, overexertion, stress, arguments and disputes' (EIROnline, 2004c). Survey evidence also indicates generally uncongenial working conditions in the Baltic states, with Latvia again a particularly poor performer (Antila and Ylöstalo, 2003; European Foundation, 2002). While employers have pursued profitability since the introduction of the market economy, workers have ranked employment security and wages over health and safety (Woolfson et al., 2003). Employers do not necessarily regard good health and safety as 'good business': externalization of the costs of injury and illness is all too easy an option. The state labour inspectorate, despite some recent improvements, is underresourced (EIROnline, 2004d). Swedish construction workers therefore perceived the arrival of Latvian contract workers on their doorstep as a threat to their hard-won wages, working conditions, and safety standards. This uncomfortable clash of histories and expectations was played out in front of a Stockholm school.

\section{The Industrial Dispute}

The origin of the dispute between the Latvian construction company, Laval un Partneri, and the Swedish trade unions stems from a municipal contract worth nearly €2.8 million to refurbish a school and build an annex in the Stockholm suburb of Vaxholm. The Latvian company, acting through a subsidiary (L\&P Baltic Bygg AB, registered in Sweden) won the contract in open competition with Swedish firms. The company was not a signatory to the $S$ wedish Construction Federation collective agreement with Byggnads, the powerful construction union with more than 100,000 members and close links to the Swedish social-democratic political establishment. The collective agreement for the sector is the most 
centralized industry-wide agreement in Sweden. Companies that are not members of the employers' organization can sign an 'application agreement' (Cremers and Donders, 2005: 52). Byggnads concludes around 1500 local collective agreements every year, 98 of these with foreign companies in 2004. Byggnads also took action against 21 companies which refused to conclude a collective agreement, 9 of which were foreign companies (Byggnads, 2004a).

Laval un Partneri has used Latvian labour to undertake various construction contracts in Sweden since 2002. In 2004, the company again imported Latvian labour, reportedly paying the 14 workers Skr80 (less than €9) per hour. Swedish workers could expect Skr130-145 (€15-16) per hour under the construction industry collective agreement; employers must also pay 12.8 percent holiday pay on top of the total wage. Laval un Partneri claimed to be paying its workers roughly twice what they would receive in Latvia, and in addition to their monetary pay, provided the workers with free accommodation, three meals a day, and transport. The company was reportedly willing to increase the agreed rate to Skr105 (nearly €12) per hour; the unions insisted, however, that the rate should be within the normal collectively bargained range for Swedish workers (European Employment Observatory, 2004).

The local section of Byggnads began negotiations with the company in early June 2004, arguing that the terms of the Swedish national agreement should apply, and the company at first said it would consider this. Thereafter, the parties met periodically, but without progress. On 14 September, the day before the fourth meeting, the company announced it had concluded a collective agreement with the Latvian Building Workers' Union (LCA), and that therefore no agreement with the Swedish union was necessary. From the viewpoint of the Latvian union, Laval un Partneri represented one of the 'better' Latvian companies; but the timing of this agreement suggests an attempt to indulge in a form of 'pre-emptive recognition'. At a further meeting in September, the company indicated it would shortly announce its decision on implementing the terms of the Swedish collective agreement, but at the beginning of October informed Byggnads that it was still considering. At this point, the union's patience ran out, and on 19 October it announced that it would initiate a blockade and prevent $\mathrm{S}$ wedish specialist services from supplying the site.

The action commenced on 2 November, some five months after the initial contact with the company (Byggnads, 2004b). The union picket at the school site continued throughout December 2004. On 2 December, Byggnads held a rally outside the parliament building in Stockholm to protest against vocal support for the Latvian position by right-wing Swedish parliamentarians. On 3 December, the electricians union (Svenska Elektrikerförbundet) called a solidarity strike. The Swedish electricians and installation employers' association duly threatened the 
union with reprisals for undertaking illegal secondary industrial action, arguing that the electricians had no right to boycott Swedish companies with signed collective agreements operating at the site. Deliveries of concrete to the Vaxholm site were also temporarily stopped, although the company managed to source supplies from a non-union firm. In midDecember, more than 50 Swedish building workers gathered at the gates to prevent the Latvian workers from entering. The police were called, but did not become directly involved, despite appeals by Laval un Partneri to the police authorities. The dispute, meanwhile, was assuming an increasingly international political dimension.

\section{Escalation}

In June 2004, a few days after the dispute commenced, the Latvian deputy foreign minister met the Swedish ambassador to Latvia to express his concern. The Swedish government was requested to intervene 'to eliminate the outright discrimination on the basis of citizenship' and 'attempts to restrict freedom of competition and the free movement of services' in the EU (Ministry of Foreign Affairs of Latvia, 2004). For its part, the Swedish Ministry of Industry, Employment and Communications conveyed the Swedish government's 'neutral' position. Prime Minister Göran Persson was quoted as saying that the Swedish union had a 'right take retaliatory measures' in order to ensure 'the survival of collective agreements' (Centre for a Social Europe, 2004). As the dispute escalated, public opinion in both Latvia and Sweden was increasingly aroused, with accusations against the Swedish trade union of 'xenophobia' and of 'protectionist mafia' behaviour. Swedish opposition parties, as well as building industry and employers' federations in Latvia and Sweden, lined up to condemn the trade union action (EUobserver, 2004). To counter the charge of being 'anti-Latvian', Byggnads placed a full-page text statement in the leading Latvian daily newspaper Diena (beneath two hands clasped in friendship) inviting Latvian workers coming to Sweden to join Swedish trade unions (Diena, 2005a). The following day, Latvian employers (this time beneath a closed fist aimed at an open hand) published a full-page counter-statement, warning Latvian workers that if they followed the Swedish union's advice, it could cost jobs (Diena, 2005b). Meanwhile, the Swedish Conservative Party's youth organization (MUF) delivered a severed horse's head (mocked-up in cloth) to the union's offices.

From the Latvian side, there were calls for an economic blockade of Swedish companies in Latvia. The Construction Contractors Association of Latvia, in a letter to Göran Håkansson, the Swedish Ambassador, observed: 'it is understandable that "old" EU member countries wish to protect their market from cheap East European workforces. They 
shouldn't forget, however, that Latvia and other new member countries wish for the same' (Dienas Bizness, 2004). Latvian trade unions, organized in Latvijas Briīvo Arodbiedrību Savienība (Free Trade Union Confederation of Latvia or LBAS), were also critical (IFBWW, 2004); their Chair, Pēteris Krīgers, expressed mystification that the Swedish unions had not contacted their Latvian colleagues prior to taking industrial action. Henceforth, it was agreed that bilateral communications would be strengthened, but the damage had been done. Perhaps, had the Latvian union confederation taken anything other than a 'national' position, it would have been pilloried domestically for 'disloyalty', especially in view of its communist past.

The Latvian authorities continued their involvement at the highest level throughout the dispute, claiming that EU rules on the free movement of services were being ignored and barriers were being placed on free competition in the internal market. Though this dispute was not directly inspired by the proposed 'Bolkestein' Directive on the liberalization of services, it may have reinforced the determination of the Latvian authorities to use the Laval case to prise open new markets in the EU. In early December 2004, the government set up an inter-ministerial working group headed by the Ministry of Foreign Affairs and involving representatives of the Ministries of Economy, Justice, and Welfare. The group concluded that the dispute constituted a breach of EU rules, and the government accordingly proposed to ask the European Commission to evaluate whether Sweden had infringed the EU Treaty. By mid-December, the Latvian Prime Minister, Aigars Kalv1 ${ }^{-}$tis, had raised the matter with the Swedish premier at an EU summit in Brussels, and personally appealed to the president of the Commission in a letter expressing 'deep concern' (Kalvi'tis, 2004). The government also announced that it might pursue the matter at the European Court of Justice (ECJ).

On 7 December, Laval un Partneri applied to the Swedish Labour Court, claiming that the industrial action and blockade were illegal, as was the sympathy strike of the electricians' union. They requested a ruling that the blockade should be lifted, and an award of damages made. In the third week of December, the court delivered its interim finding: 'actions like this aimed at pushing through an add-on to the leading collective agreement within the industry, cannot be seen as going against good labour market practices' (EUbusiness, 2004). Hans Tilly, Chair of Byggnads, welcomed the ruling:

For us it has been obvious the whole time that Swedish rules and laws should apply for everyone in the Swedish labour market, regardless of what country they come from... The Labour Court's decision today clarifies that the Latvian [collective] agreement will not block us from continuing our actions aimed at getting Laval un Partneri to sign a Swedish collective agreement. (EUbusiness, 2004) 
Lawyers for the company intimated that they would seek to appeal, while Diena reported promises by Tilly to escalate the industrial action in the New Year:

We expected such a verdict, anything else would be unacceptable. We will continue the blockade until the company sign the collective work contract. We have the right to use the blockade as a sanction against companies that refuse to cooperate with us and we will certainly expand the blockade. It is a good feeling that we can carry on our traditions and protect workers from insatiable companies. The blockade will involve industrial, metalworking, woodworking, transport and construction trade-unions, as well as the union of (building maintenance) tradesmen.

(Diena, 2004)

The dispute also took on an international trade union character. The 10-million-strong International Federation of Building and Wood Workers (IFBWW) launched a solidarity campaign, issuing a letter of protest to be sent to the Latvian government, to Laval un Partneri, and to Svenskt Näringsliv (Confederation of Swedish Enterprise). In early January 2005, as the trade unions intensified their boycott, Laval un Partneri declared that they were not prepared to give up their operations in Sweden, despite considerable financial losses (Baltic Times, 2005; LETA, 2004). The dispute seemed set to become even more intractable. One month later, however, as trade union pressure on the company mounted, and the Vaxholm municipality became increasingly concerned over contract completion, Laval un Partneri announced their withdrawal from Sweden. Though the municipality offered to pay the company for work carried out up to the point at which the blockade had commenced, the firm had reportedly suffered considerable losses, their Swedish subsidiary filing for bankruptcy (Dienas Bizness, 2005a).

\section{The Posted Workers Directive and Transitional Arrangements}

At first glance, this looked like a victory for Swedish organized labour. However, the dispute has exposed underlying weaknesses in the application of European labour regulation, which could produce different outcomes in the context of a weaker labour movement. The crucial issue is the interpretation of the 1996 EU Directive (96/71/EC), which stipulates that workers 'posted' by an employer to perform work in another EU state should be guaranteed the minimum provisions laid down by law or collective agreement in the host country. The meaning is straightforward in countries where core employment conditions are specified by statute or in agreements which are given universal applicability by law 
(erga omnes). Where (as in Sweden) this is not the case, the Directive (Article 3.8) enables a country to specify as the minimum the terms of 'collective agreements which have been concluded by the most representative employers' and labour organizations at national level, and which are applied throughout the national territory'.

This provision recognizes the distinctive character of the Scandinavian labour market model, which rests on voluntary collective agreements without erga omnes procedures, and was regarded as a major victory for trade unions in Sweden and Denmark. This issue was on the table during Sweden's EU application negotiations in 1994-95 and resulted in a declaration, annexed to the accession agreement, which stated that Sweden could maintain its labour market model. Accordingly, collective agreements in themselves were held to be an adequate method of implementing Community law in Sweden.

The Directive was transposed into Swedish legislation through the 1999 Posting of Workers Act, which set out a list of the rules that must be observed by all employers, whether established within or outside the EU (Ministry of Industry, Employment and Communications Sweden, 1999). This list corresponds to that given in the Directive (Article 3.1), except that there are no rules corresponding to the latter's provisions regarding minimum rates of pay laid down by law or collective agreement, and on terms and conditions in collective agreements for the building sector (EMIRE, n.d. a, n.d. b). Swedish trade unions seek to guarantee minimum wages and holiday pay entitlements exclusively through collective bargaining. If necessary, such collective agreements could be defended through industrial action in order to prevent 'social dumping' (Rönngren, 2005: 2).

The issue of social dumping arose directly in the context of heightened sensitivities after EU enlargement. LO Vice-President Erland Olausson warned that the Laval dispute: 'concerns the entire Swedish labour market. Every worker will be affected if dumping of Swedish salaries is permitted ... We do not accept social dumping which is competition on the lowest level of salary and working conditions' (EUobserver, 2004). However, the issue of social dumping has been the subject of a longstanding concern in Sweden following the portside boycott of a flag-ofconvenience vessel with a poorly paid Filipino crew, the MS Britannia. This resulted in a 1989 Labour Court judgment severely restricting industrial action aimed at replacing or amending an existing collective agreement applicable to a given workplace ... even if the union taking such action was not bound by the agreement concerned' (EMIRE, n.d. a, n.d. b). The judgment made the ban on industrial action applicable to both Swedish and foreign employment relationships. After intense trade union lobbying, an amendment to the 1976 Co-Determination Act was enacted in 1991. Popularly known as Lex Britannia (EMIRE, n.d. a, n.d. 
b), this gave Swedish trade unions the right to take collective action, such as boycotts and blockades, in connection with employment relationships which are not governed by Swedish law (for example, in respect of the activities of a foreign enterprise temporarily working in Sweden) if the unions consider this a case of social dumping. Such action was allowed even if the union in question had no members at the site or enterprise, and even if there was a valid collective agreement applicable to the workers' or the company's home country. In practice, Lex Britannia provided the means for Swedish trade unions to enforce the posted workers Directive, and the conflict with Laval un Partneri must be seen against this background. In sum, Swedish practice attempts to reconcile EU Directives with a non-statutory approach to labour market regulation. This is a significant strength, if based on continuing high levels of union density, but also a potential weakness in the context of diminishing collective bargaining power. The Laval dispute highlighted the fact that, with no minimum wage legislation or universally binding collective agreements, a foreign company could argue that there was no obligation upon it to pay a specified wage.

A problematic feature in the host-state application of the posted workers Directive, highlighted by the dispute, is its potential incompatibility with the EU Treaty provisions (Article 49, formerly Article 59) giving enterprises the right to engage freely in the cross-border provision of services. A firm which has to comply with labour standards reflecting the host state's higher wages and standards of labour protection could claim that it is being denied a basic freedom endowed in the EU Treaty, and at the same time placed at an 'unfair' competitive disadvantage. ECJ case law began to deal with these matters in the early 1990s. The first notable ruling, issued in March 1990 (ECJ, case C-113/89, Rush Portuguesa [1990] ECR I-1417/12), concerned a Portuguese-owned public works company which had been subcontracted to build a railway line in France. The ECJ ruled that the company had the right (based on freedom to provide services guaranteed by the Treaty) to carry out the contract using its own Portuguese workers. However, it also ruled that French social and labour legislation was applicable to the contract and that France therefore had the right to extend collective agreements to foreign enterprises temporarily carrying out work in France. To clarify this principle and, in part, to moderate the wide-ranging nature of this judgment, the Commission subsequently issued its Directive on posted workers (Davies, 2002). In the intervening years, as the case law has expanded, the Commission has sought to keep the implementation of the provisions of the Directive under review, although so far without proposing amendments (EC, 2003).

A further difficulty has involved the so-called 'transitional arrangements' with regard to the free movement of labour within an enlarged EU. 
Posted workers are only temporarily working in another member state, remaining employed in their home state, and thus are not 'mobile' in the sense that transitional arrangements address. Nevertheless, there is a perception of labour 'leakage' into the receiving country's labour market, which means that the two areas of policy are increasingly intertwined in the minds of political and economic actors. In reality, the notion that posted workers 'do not enter the host state labour market' is often little more than a legal fiction. At 'site level' the provisions of the posted workers Directive are often not observed, and practical enforcement is difficult. Transitional arrangements to limit the inflow of labour from the new member states currently exist in most EU-15 countries for a two-year period following enlargement. However, the issue is highly sensitive, and poses a massive dilemma for the Commission and national governments. At the end of the transitional period, member states must notify the Commission as to their intentions for the next three years, either to maintain measures to limit inflows or to permit free movement of labour. By 2009, the Commission expects to achieve the free movement of workers on a Europe-wide basis. A current member state can apply for authorization to continue national measures for a further two years, but only if the requirement can be 'objectively justified'. In any event, by 2011, seven years after the 2004 enlargement, complete freedom of movement of labour must be guaranteed (EC, 2002; European Commission Memo, 2004; Turmann and Carrera, 2004). These transitional arrangements do not apply to certain categories of persons, for example, those wishing to study in an existing member state or those seeking to establish themselves as 'self-employed' persons. Moreover, transitional periods do not apply to the free movement of services, including posted workers; and in Austria and Germany, the exemption from transitional arrangements is specifically removed from labour in the construction sector. In this context, a lack of definitional clarity in national law on the question of employment status, especially with regard to the notionally 'self-employed', remains a key weakness of the posted workers Directive and further complicates the issue (Cremers and Donders, 2005: 138-9).

For the Swedish authorities, the Laval dispute poses acute difficulties, in addition to the vulnerabilities it revealed in the national transposition of the posted workers Directive. Sweden was one of the few member states not to restrict the future free movement of labour, but could certainly now ask the Commission to impose such restrictions. It would then be up to the Commission to decide what restrictions, and for which period, might be allowed. The Swedish authorities may be forced to follow the Austrian and German route of seeking a specific further exclusion of the notionally 'self-employed' in construction, especially if new member state employers attempt to circumvent additional restrictions. For each actor, however, there are costs in pursuing whichever 
strategy is adopted. For the European project as a whole, this seemingly small labour dispute could potentially undermine much of the legitimacy that has been created for a viable identity of 'European citizenship' in the post-communist member states, reinforcing their perception of 'secondclass' citizenship.

\section{Race to the Bottom?}

A number of questions which arise from the dispute are troubling, but perhaps unanswerable. Why was the Laval tender accepted by a Swedish public authority in the first place (when it must have been clear that Swedish collective agreement conditions were not to be applied)? Why were the Latvian authorities so eager to become involved at the highest levels from the very inception of the dispute? How could a relatively small contractor survive such a protracted dispute (without at least some form of political and financial encouragement)? Some argue that the dispute was stoked up by the Swedish and Latvian employers, and the Latvian authorities, using Latvian workers as a pawn.

Even as the Laval episode was unfolding, trade union pressure forced an Estonian labour agency based in Stockholm to withdraw two Estonian workers who were employed at a ski resort and paid less than half the minimum wage of Swedish workers. At around the same time, a Lithuanian construction company, Atkirta, abandoned a project in Denmark under similar trade union pressure. Neither of these episodes attracted more than passing attention. The admission by Svenskt Näringsliv that it funded Laval's case before the Labour Court to the sum of half a million kronor $(€ 55,000)$ (Svenska Dagbladet, 2005) suggests that the Laval episode provided a convenient point of entry for employers' organizations to open up 'strategic' long-standing issues of labour market reform in Sweden (Hamilton, 2005). Meanwhile, in a move that may well be problematic in terms of EU requirements on free competition, the Swedish government has intimated that it will prohibit the awarding of public contracts without an appropriate collective agreement. The Minister for Local Government and Financial Markets, Sven-Erik Österberg, told the Swedish media:

We [in Sweden] have a different tradition than what is usual further south in Europe ... It is extremely important that we show that we can enforce the collective agreement in Sweden also in the future ... In light of among other things what happened in Vaxholm, this has become very pressing. (The Local, 2005a)

In a further twist to the saga, the Swedish Labour Court, in an apparent step back from earlier certainties, has decided to seek a preliminary 
opinion from the ECJ before making its own final ruling on the Laval case, because European legislation is 'unclear concerning the issue of whether the [blockade] actions are compatible with a ban on impeding the free circulation of services and a ban on discrimination ... as well as the directive 96/71/EC on the posting of workers abroad' (EUbusiness, 2005). Such a ruling may take at least two years to emerge, and therefore adds to the uncertainties that surround this issue. Meantime, new disputes involving Latvian construction companies, similar to the Laval episode, appear to be emerging (The Local, 2005b).

At European level, a group of some 40 assorted Nordic and Baltic Members of the European Parliament, belonging to the European People's Party (Christian Democrats and conservatives), seem determined that this dispute should remain a cause célèbre. They have sought an affirmative response from a sympathetic Commission on the question of the free movement of services and 'discrimination' against new member states (Dienas Bizness, 2005b). Subsequently, EU Internal Market Commissioner, Charlie McCreevy, announced (in advance of a 'common position' from the Commission) that he would oppose Sweden and support Laval's position when the case comes before the ECJ. This news caused consternation in Sweden, where the government threatened to withdraw its previous political support for the draft Services Directive, and provoked uproar in the European Parliament (EUobserver, 2005a, $2005 \mathrm{~b}, 2005 \mathrm{c}$ ). The issues raised by Laval have thus become entangled with the debate on the future Services Directive and the European social model in general.

\section{Conclusion}

It will be tempting for new member states such as Latvia to use their 'comparative advantage' in low wages and inferior working conditions to reach some parity within the liberalized EU. However, any gains would be short-lived if they depress the wages and working conditions of their wealthier neighbours. In terms of the protective aspects of the posted workers Directive, its 'public policy provisions' (Article 3.10) are meant to offer some measure of reassurance that a floor of minimum standards will be maintained. It is the core provisions of the Directive which are its ultimate guarantee of efficacy, however, and these now seem to be under threat. Furthermore, the contentious designation of the 'country of origin principle', in whatever convoluted form it eventually emerges in the proposed Services Directive, may radically alter the ability to defend national labour standards, even though workers already covered by the posted workers Directive will be theoretically subject to specific derogation in order to prevent social dumping. 
In the first draft at least of the proposed Directive, companies wishing to provide services in more than one country would be able to operate according to the rules and regulations of their home country, rather than those of the host country. Thus companies in existing member states would potentially be able to bypass strong social and environmental standards by shifting their operational base to new member states with less rigorously enforced labour laws and agreements, while new member state companies would be able to undercut at will. As if to reinforce such fears, a Latvian recruitment agency Eiropas Eksperti (European Experts) makes the following offer on its website:

You don't pay any employers or social taxes for the workers you rent from us. You also slip employers responsibility, because employer of the workers is still our company. We send our workers to perform the work at your company ... You get highly motivated employees with good knowledge of English/German. You save $50 \%$ or more on salaries if you compare with the wage you would have to pay to nationals of your country. We offer our services in whole European Union and especially in Great Britain, Germany, Netherlands and Nordic countries (Sweden, Finland, Denmark). Our workers are experienced, hard working, attractive and mostly work in restaurants and cafes, storehouses, transport companies, agriculture and construction sectors. But even workers in IT and other areas can be offered. Make your company more competitive and discover the opportunities new EU has to offer! (Eiropas Eksperti, 2005)

There is a reply form on the website which interested enquirers can email to Eiropas Eksperti, complete with tick-boxes to list the number and type of workers required.

Today, the challenges of labour mobility and European integration are vexing. The contention of Laval un Partneri that it has a right to enter Swedish labour markets by virtue of adhering to Latvian labour law and the 'freedoms' of the internal market is a threat to labour rights in Sweden and, such as they are, in Latvia. This dispute reflects the difference between advanced democratic societies with strong labour movements and what, despite the sustained efforts of many in the Baltic States, are still often electoral oligarchies in which labour rights are routinely sacrificed in the search for economic prosperity. The current imbalance of power in post-communist states such as Latvia, in which organized labour is largely silent (or indeed silenced), makes for potentially insurmountable obstacles to the achievement of modern European-style industrial relations. The notion of labour as a legitimized 'social partner' with the right to engage freely in collective bargaining is daily contradicted both in law and practice. While the mutual participation of social partners may have contributed to the prosperity experienced by western Europe after 1945, it is a concept as yet little understood in the new member states. 
The history of democratic advance has been one of collective reaction against the raw power of market forces. If organized labour views the gains of 'Europeanization' as largely ephemeral, and merely a pretext for private power to profit at its expense by initiating a 'race to the bottom' in labour standards, it will defend itself both on an international and a national basis, in so far as it is able to do so, much as Swedish workers have done. One certainty remains, if the strongest of labour movements, such as the Swedish trade unions, were to be unable to defend their interests, this would be a historical setback for the entire European trade union movement. Even short-term success will not necessarily resolve underlying issues which inevitably will reappear, perhaps in an even more destructive form. A likely outcome will be populist resistance to labour mobility, based on ethnic prejudice.

It could be argued that the Laval episode reveals more about fragilities in the 'Scandinavian model' of labour market regulation, in particular its incomplete transposition of the posted workers Directive into Swedish law, than deficiencies in a European social model as such. Given that the Directive has hitherto been implemented in Sweden (and Denmark) by collective agreement, such an argument may be persuasive at first glance. Indeed, the LO has warned that if Sweden is forced to introduce national minimum wages or legislation to extend the scope of collective agreements, it would mean 'the end of the Swedish labour market model' (Rönngren, 2005). In the light of the Vaxholm episode, a broad framework agreement between Swedish employers and the LO on the issue of incoming foreign labour has now been reached, although this has still to be developed in sectoral agreements (LO, 2005).

Paradoxically, non-legally binding arrangements based on close cooperation between the social partners are precisely the model of the open method of coordination currently evolving at EU level and strongly encouraged by the Commission. 'Traditional' Community instruments such as Directives are increasingly regarded as an unnecessary 'burden' on business and competitiveness, while 'soft law', 'better regulation', and voluntary self-regulation by social partners are promoted as alternative regulatory strategies. Yet as the Laval un Partneri dispute suggests, even in the most favourable circumstances, where voluntary collective bargaining arrangements are strongly entrenched, standards of labour protection are vulnerable without a supporting architecture of national law. If anything, such vulnerability is likely to increase as similar disputes arise, both in Sweden and in other less favourable industrial relations arenas, and as future EU enlargement intensifies pressures on labour standards. Ultimately, the challenge is not simply one way, from East to West, but in the reverse direction as well. The new member states may also have less incentive to modify their industrial relations frameworks to ensure the active implementation of 
labour rights in line with international standards, adding yet a further twist to the downward spiral.

\section{ACKNOWLEDGEMENTS}

The authors are grateful to Noam Chomsky, Linda Clarke, Jan Cremers, Jan Druker, the late Andre Gunder Frank, Sam Hägglund, Richard Hyman, Jan-Olof Ronn and Christer Thörnqvist for their comments on earlier drafts of this article. The authors alone remain responsible for any subsequent errors and omissions.

\section{REFERENCES}

Antila, J. and Ylöstalo, P. (2003) Working Life Barometer in the Baltic Countries 2002. Helsinki: Ministry of Labour.

Antila, J. and Ylöstalo, P. (2004) 'Reunionisation in the Baltic Countries'. IIRA 7 th European Congress, Lisbon, September.

Baltic Times, The (2005) 'More Unions Join the Blockade'. 13 January: 4.

Byggnads (2004a) The Blockade in Vaxholm. Stockholm: Byggnads.

Byggnads (2004b) 'Byggnads' Industrial Conflict with Laval un Partneri Ltd Affects the Whole of Europe', Official briefing document prepared by the Nordic Federation of Building and Wood Working Unions. Stockholm: Byggnads.

Centre for a Social Europe (2004) 'Accused of Wage Dumping, Latvian Construction Group Talked on Swedish Union', URL: (20 December) http://www.social-europe.org.uk/presscuts/041220afp.htm.

Clarke, L., Cremers, J. and Janssen, J. (eds) (2003) EU Enlargement: Construction Labour Relations as a Pilot. Brussels: CLR Studies.

Cremers, J. and Donders, P. (eds) (2005) Free Movement of Workers in the EU. Brussels: CLR Studies.

Davies, P. (2002) 'The Posted Workers Directive and the EC Treaty', Industrial Law Journal 31(3): 298-306.

Dennis, I. and Guio, A. (2003) Monetary Poverty in the EU Acceding and Candidate Countries, Statistics in Focus, Population and Social Conditions, Theme 3, 21/2003. Eurostat.

Diena (2004) 23 December.

Diena (2005a) 31 January.

Diena (2005b) 1 February.

Dienas Bizness (2004) 'Threats to Swedish Constructors'. 23 November: 6.

Dienas Bizness (2005a) 'Agreement to be Broken with Laval'. 11 February: 3.

Dienas Bizness (2005b) 'Reminder about Laval'. 4 October: 3.

Druker, J. and Dupré, I. (1998) 'The Posting of Workers Directive and Employment Regulation in the European Construction Industry', European Journal of Industrial Relations 4(3): 309-30.

EC (European Commission) (2002) Free Movement for Persons: A Practical Guide for an Enlarged European Union. Brussels: EC Commission.

EC (2003) 'The Implementation of Directive 96/71/EC in the Member States', Communication from the Commission to the Council, the European 
Parliament, the Economic and Social Committee and the Committee of the Regions, 25.7.2003, COM(2003) 458 final. Brussels: EC Commission.

EIROnline (2004a) 'Latvia: 2003 Annual Review for Latvia', URL: http://www. eiro.eurofound.ie/2004/01/feature/lv0401102f.html.

EIROnline (2004b) 'Latvia: The Development and Current Situation of Trade Unions', URL: http://www.eiro.eurofound.ie/2004/03/feature/lv0403104f. html.

EIROnline (2004c) 'Latvia: Numbers of Workplace Accidents Increasing', URL: http://www.eiro.eurofound.ie/2004/04/inbrief/lv0404102n.html.

EIROnline (2004d) 'Latvia: State Labour Inspectorate Examined', URL: http://www.eiro.eurofound.ie/2004/04/feature/lv0404101f.html.

EIROnline (2004e) 'Latvia: Thematic Feature: Industrial Relations and Undeclared Work', URL: http://www.eiro.eurofound.ie/2004/06/feature/ lv0406103t.html.

EIROnline (2004f) 'Latvia: Industrial Relations Aspects of Public Employment Policy Analysed', URL: http://www.eiro.eurofound.ie/2004/07/feature/ lv0407102f.html.

EIROnline (2004g) 'Latvia: Pay Demands by Medical Staff Spread', URL: http://www.eiro.eurofound.ie/2004/12/inbrief/lv0412103n.html.

Eiropas Eksperti (2005) 'Welcome to the Place Where Money of Europe Becomes Yours', URL (consulted November 2005) http://www.eiropaseksperti.lv/modules/tinycontent/index.php.

Elvander, N. (2002) 'The New Swedish Regime for Collective Bargaining and Conflict Resolution: A Comparative Perspective', European Journal of Industrial Relations 8(2): 197-216.

EMIRE (n.d. a) 'Posted Workers Directive'. Dublin: European Foundation. EMIRE (n.d. b) Lex Britannia. Dublin: European Foundation.

EUbusiness (2004) 'Swedish Court Rules Against Latvian Company Accused of Wage Dumping', URL (22 December) http://www. EUbusiness.com/afp/ 041222164857.a03jwep.

EUbusiness (2005) 'European Court to Rule on Latvian Wage Dumping

Dispute with Sweden', URL: (29 April) http://www. EUbusiness.com/afp/

050429190442.25lvyvfk/view.

EUobserver (2004) 30 November.

EUobserver (2005a) 6 October.

EUobserver (2005b) 13 October.

EUobserver (2005c) 17 October.

European Commission Memo (2004) 'The Free Movement of Workers Following Enlargement', info BASEEUROPE, URL: (9 February) http://www.ibeurope.com/Records/7500/7500.htm.

European Employment Observatory (2004) 'Monthly Newsletter', No. 21, December, URL: http://www.eu-employment-observatory.net/resources/ monthlyupdates0412/latvia_update_dec_04.doc.

European Foundation (2002) First Survey of Working Conditions in the Accession and Candidate Countries. Dublin: European Foundation.

Eurostat (2004) New Cronos Database, Structural Indicators, Employment, Fatal Accidents at Work. Luxembourg: Eurostat.

Gowan, P. (1999) The Global Gamble. London: Verso. 
Hamilton, E. (2005) 'The Road from Vaxholm, via Riga, to Luxembourg: Why Does the Confederation of Swedish Enterprise Support Laval un Partneri in its Struggle Against Swedish Trade Unions?', MSc Dissertation. London School of Economics.

IFBWW (2004) 'IFBWW Solidarity Campaign and Trade Union Rights Flash: Support IFBWW Swedish Affiliate Byggnads in its Conflict Against Latvian Construction Company L \& P Baltic Bygg AB!' Geneva: IFBWW.

IMF (2004) 'Latvia: 2004 Article IV Consultation Concluding Statement of the IMF Mission’, 29 April. URL: http://www.imf.org/external/np/ms/2004/ 042904.htm.

Kalvìtis, A. (2004) Letter to HE Mr José Manuel Barroso, The President of the European Commission, cc Mr Charlie McCreevy, The European Commissioner responsible for Internal Market and Services, Riga, 15 December (in authors' possession).

Kohl, H. and Platzer, H. (2004) Industrial Relations in Central and Eastern Europe: Transformation and Integration: A comparison of the eight new EU member states. Brussels: ETUI.

Kvist, J. (2004) 'Does EU Enlargement Start a Race to the Bottom? Strategic Interaction Among EU Member States in Social Policy', Journal of European Social Policy 14(3): 301-18.

Latvian Investment and Development Agency (2004) Business Incentives in Latvia. URL: http://www.liaa.gov.lv/eng/Incentives/.

LETA (2004) ““Laval\&partneri” Vaksholmābūvniecību tomēr neatsāks', URL: (5 January) http://www.delfi.lv/news/national/politics/article.

LO (2005) 'Rekommendation av Svenskt Näringsliv och Landsorganisationen i Sverige (LO) om anpassning av förbundsavtal för företag som blir tillfälliga medlemmar I arbetsgivareförbund inom Svenskt Näringsliv', 30 August. URL: http://www.lo.se/home/lo/home.nsf/unidView/B96225EF07D58710C 125706D00305195/\$file/utlforetagslutligversion30aug05.pdf.

Local, The (2005a) 'Sweden Pushes to Protect Collective Agreements'. 7 April. URL: http://www.thelocal.se/article.php?ID=1240\&date=20050407.

Local, The (2005b) 'Builders Union Threatens New Blockade'. 10 May. URL: http://www.thelocal.se/article.php? ID $=1408 \&$ date $=20050510$.

Mailand, M. and Due, J. (2004) 'Social Dialogue in Central and Eastern Europe: Present State and Future Development', European Journal of Industrial Relations 10(2): 179-97.

Ministry of Foreign Affairs of Latvia (2004) 'News: Under-Secretary of State of the Latvian Foreign Affairs Ministry meets the Swedish Ambassador to Latvia', 17 November. URL: http://www.am.gov.lv/en/eu/news/4341/?ng $=5318$.

Ministry of Industry, Employment and Communications Sweden (1999) Foreign Posting of Employees Act, SFS 1999: 678.

OECD (2003) Labour Market and Social Policies in the Baltic Countries. Paris: OECD.

Ost, D. (2000) 'Illusory Corporatism: Tripartism in the Service of Neoliberalism', Politics and Society 28(4): 503-30.

Palley, T. (1998) Plenty of Nothing. Princeton, NJ: Princeton University Press. Renooy, P., Ivarsson, S., Van der Wusten-Gritsai, O. and Meijer, R. (2004) 
'Undeclared Work in an Enlarged Union: An Analysis of Undeclared Work: An In-Depth Study of Specific Items', Final report, May. URL: http:// europa.eu.int/comm/employment_social/employment_analysis/work/undecl _work_final_en.pdf. Brussels: European Commission, Directorate-General for Employment and Social Affairs.

Republic of Latvia (2004) 'GDP in the 9 months of 2004 increased by 8.5 percent', Press release, 12 December. Riga: Republic of Latvia, Central Statistical Bureau.

Rönngren, B. (2005) 'The Directive on the Posting of Workers: The Case of Sweden', Information note, 4 February. Stockholm: LO.

Russell, H. and Whelan, C. (2004) Low Income and Deprivation in an Enlarged Europe. Dublin: European Foundation.

Sandberg, B., Odgaard, G., Lubanski, N., Bonke, S. and Pedersen, E.F. (eds) (2004) Free Mobility and EU's Enlargement: Migration of the Construction Workers After May 2004, Bygg Rapport R-081. Lyngby: CLRdenmark/ BYG.DTU.

Stokke, T. and Thörnqvist, C. (2001) 'Strikes and Collective Bargaining in the Nordic Countries', European Journal of Industrial Relations 7(3): 245-67.

Svenska Dagbladet (2005) 'Pengastöd till lettiskt byggföretag'. 13 June. URL: http://www.svd.se/dynamiskt/naringsliv/did_9934110.asp.

Turmann, A. and Carrera, S. (2004) Towards a Free Movement of Workers in an Enlarged EU? Brussels: CEPS.

Vaughan-Whitehead, D. (2003) EU Enlargement Versus Social Europe: The Uncertain Future of the European Social Model. Cheltenham: Edward Elgar.

Woolfson, C., Beck, M. and Šceponavicius, A. (2003) 'Workplace Safety and Health in Pre-Accession Lithuania: A Survey', Policy and Practice in Health and Safety 1(1): 59-81.

Zepa, B. (ed.) (2004) Ethnic Tolerance and Integration of the Latvian Society. Riga: Baltic Institute of Social Sciences.

CHARLES WOOLFSON is Marie Curie Chair at the University of Latvia (2004-07) and Professor of Labour Studies, University of Glasgow. He has published on corporate social responsibility, working environment issues, and industrial relations, especially in the new EU member states.

ADDRESS: School of Law, The Square, University of Glasgow, Glasgow G12 8QQ, UK. [e-mail: C.Woolfson@law.gla.ac.uk]

JEFF SOMMERS is Assistant Professor at Raritan Valley College, USA, and Visiting Professor at the Stockholm School of Economics in Riga. He has written extensively on development issues and the political economy of the post-Bretton Woods order.

ADDRESS: Stockholm School of Economics in Riga, Strelnieku 4a, Riga, LV-1010 Latvia. [e-mail: jsommers@fulbrightweb.org] 